\title{
Abandoned Mine, Potential Home for the People: A Case Study of Jos Plateau Tin-Mining Region
}

\author{
Samuel Danjuma Wapwera ${ }^{1}$, Grace Mebi Ayanbimpe ${ }^{2}$ and Charles Egbu Odita ${ }^{3}$ \\ 1. Department of Urban and Regional Planning, University of Jos, Jos Plateau State +234 , Nigeria \\ 2. Department of Medical Microbiology, University of Jos, Jos Plateau State +234, Nigeria \\ 3. School of the Built Environment, Salford University, Salford M5 4WT, UK
}

\begin{abstract}
This paper seeks to examine the JPTMR (Jos Plateau Tin-Mining Region) as an abandoned mine that provides land for housing by examining the impact of the tin-mining activities due to the presence of heavy metals and radioactive substances and analyzing the level and availability of these substances and their effects on human health and the built environment within JPTMR. Utilizing secondary data, which map out 10 different locations in the region, the paper highlights the level of radioactive substances (X-ray, beta-ray and gamma-ray) and presence of heavy metals in the environment. The results show that there are traces of X-ray, beta-ray and gamma-ray as well as the heavy metals such as $\mathrm{Pb}, \mathrm{As}, \mathrm{Cu}, \mathrm{Cr}$ and $\mathrm{Ni}$ which exceeded the international standards. This is particularly significant as people use the contaminated soils as building materials for their homes as well as for farming and food production. The inhabitants of the area are often without any knowledge about the perils of the contaminated soils, water as well as air which is serious long-term human catastrophe. Drawing from international experience, the paper argues that it is possible to develop housing in former tin-mining areas but requires careful remediation and engagement by the public and private sector.
\end{abstract}

Key words: Abandoned mines, contaminated land, housing development, home.

\section{Introduction}

Housing is a major component of the built environment, and it is affected by other components of the environment such as the facilities, services and utilities as well as other infrastructure associated with it. Humans' social, economic and political activities have profound impact on the natural environment. The production of the built environment has a major impact on the environment including climate change and environmental change that create health problems [1-8].

In Nigeria, the 2006 national housing policy was formulated with the ultimate goal of ensuring that all Nigerians own or have access to decent accommodation at an affordable cost within a healthy environment. Despite the level of progress being made

Corresponding author: Samuel Danjuma Wapwera, Ph.D., research fields: urban and regional planning, housing, development, and management and theories. E-mail: s.d.wapwera@edu.salford.ac.uk. in industry, education and services, the simple refuge in affording privacy and protection against the forces of nature is still beyond the reach of many, especially the poor and the disadvantaged [6, 9-11]. Jinadu [12] highlighted qualities of a good house to meet the needs of the occupant in his study, thus a good house should have a quiet environment, privacy, clean, living and outdoor space, safety and aesthetic satisfaction. A house must also have good quality building materials which meet the needs and aspirations of the occupants as well as contribute to physical, mental and social well-being of the individuals. It should also be served with the basic community facilities like roads, electricity, water, recreational facilities and sewage/refuse disposal [4, 8, 13-16].

The quality of housing remains an issue of concern to developers, builders, policy makers as well as planners. Studies have shown that majority of low income earners and the poor in the developing countries live in substandard housing and poor quality 
neighbourhoods. This is more prevalent in the rural areas, mainly because the houses are constructed using low quality building materials. The situation is worse, in environments characterised by environmental degradation, derelict lands and environment pollution among others giving rise to a poor environmental quality, which in turn affects human health due to the presence of heavy metals and radioactive substances as well as microbial contaminants as products of tin-mining activities (Figs. 1 and 2) [8, 12, 14, 17-20].

Mining as a process of extraction of raw materials for industrial use can leave behind a legacy of environmental pollution for generations to come $[21,22]$. In many developing countries due to lack or weak policies and regulative measures, mining has caused severe environmental pollutions that are hazardous to the immediate local residents in the area. Mining activities took place in Jos Plateau, Nigeria, over a century ago leaving behind ponds posing a danger, and constraining the movement of people, goods and animals. Hence, the zone is tagged "disaster" area [15, 16, 23-25].

The Jos Plateau Tin-Mining Region of Nigeria is located on a granite plateau, $1,900 \mathrm{~m}$ above sea level in the north central part of Nigeria as shown in Fig. 3. The geological formation of this area lends itself to the lithological formations composed of the basement complex, biotite granite and new basalts as observed by Macleod et al. [20], Ajayi [26] and Turner [27]. Tin and columbite ore are associated with greisenized, biotite granites. The Jos Tin Industry started around 1904. The primary purpose of the industry is to mine tin ore and mill the same for tin and some by-products (especially columbite) for exportation. The rock materials are used extensively for slabs, aggregates, rockfills and other forms in building construction in and around Jos, and this continued to increase as more and more people built houses to cater for the increasing need for accommodation.

Jos Tin-Mining Region is located in the northern and central parts of Jos Plateau State, north central geo-political region of Nigeria. It is bounded approximately by latitudes $8^{\circ} 00^{\prime} 55^{\prime \prime} \mathrm{N}$ and $10^{\circ} \mathrm{N}$, and longitude $8^{\circ} 00^{\prime} 22^{\prime \prime} \mathrm{E}$ and $9^{\circ} 00^{\prime} 30^{\prime \prime} \mathrm{E}$ and the locations of the samples collected according to Gyang and Ashano [28] were latitude $9^{\circ} 30^{\prime} \mathrm{N}$ and $9^{\circ} 33^{\prime} \mathrm{N}$ and longitude $8^{\circ} 53^{\prime} \mathrm{E}$ and $8^{\circ} 59^{\prime} \mathrm{E}$. It is one of the many geographical (physiographic) regions recognized in Nigeria (Fig. 4).

The choice of the Jos Plateau Tin-Mining Region is informed by the fact that the region covers nine local government areas and six carved as the state capital being the metropolis. The tin-mining activity that started in 1904 gave the city the name "Jos Tin City". It is one of the colonial cities inhabited by the British colonial masters, as a result of the tin-mining activities and a region with planned layers of good grid-system in 1920. The region houses the old township under the 1917 Town Planning Ordinance as observed by Bingel [29]. Presently, it has a population of over 1.5 million according to Refs. [30, 31].

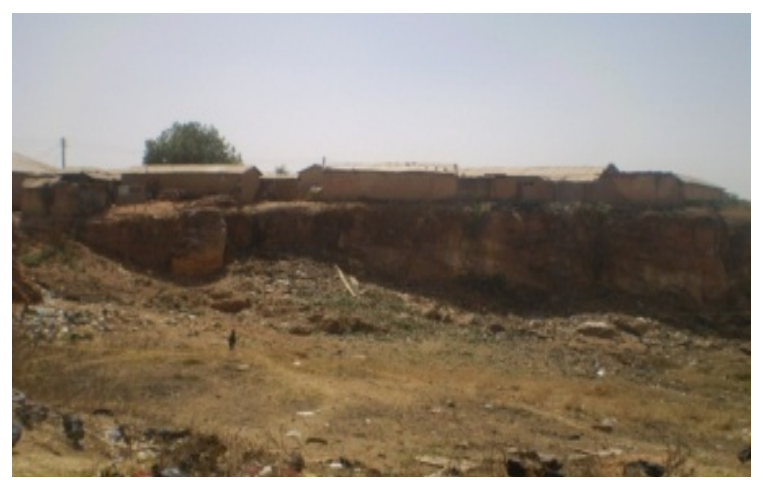

Fig. 1 Location of housing close to mining ponds. Source: reconnaissance survey, 2009.

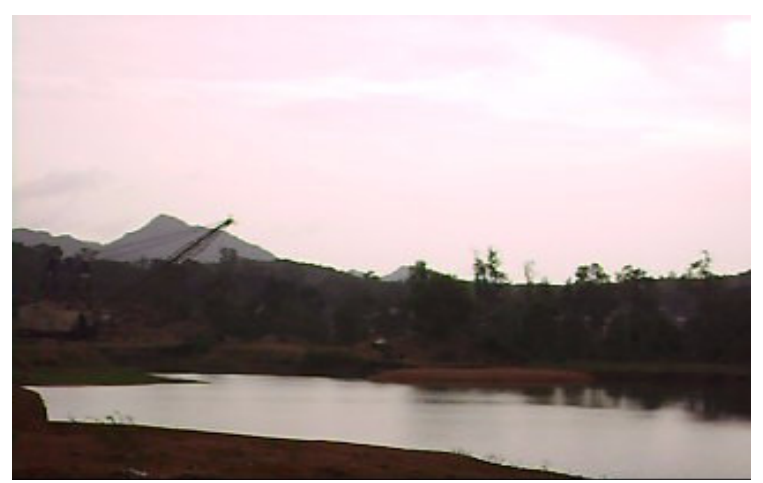

Fig. 2 Location of dragline to form mining ponds. Source: reconnaissance survey, 2009. 


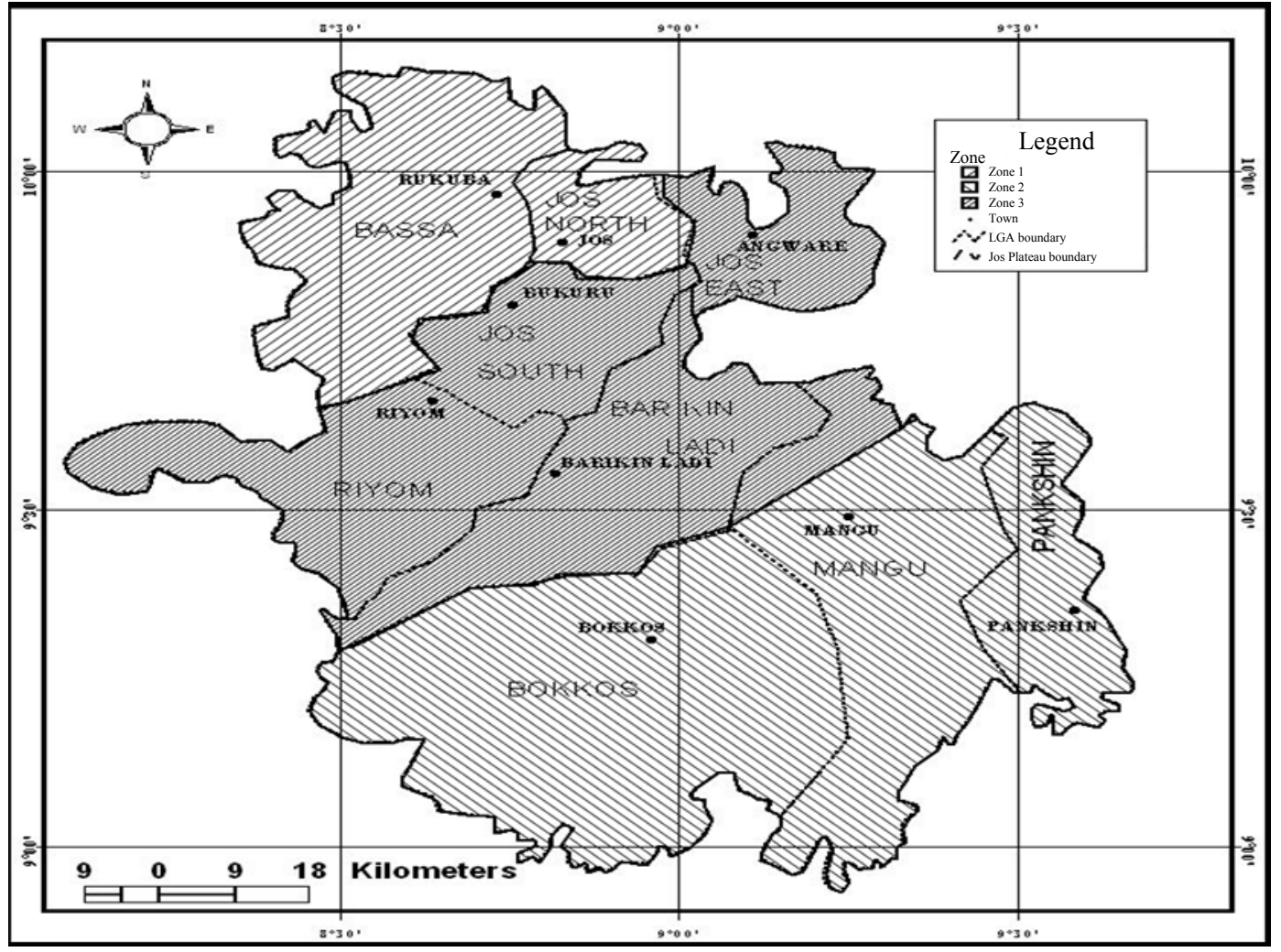

Fig. 3 Jos Plateau Tin-Mining Region.

Source: GIS (geographic information system) Lab, University of Jos, Nigeria, 2008.

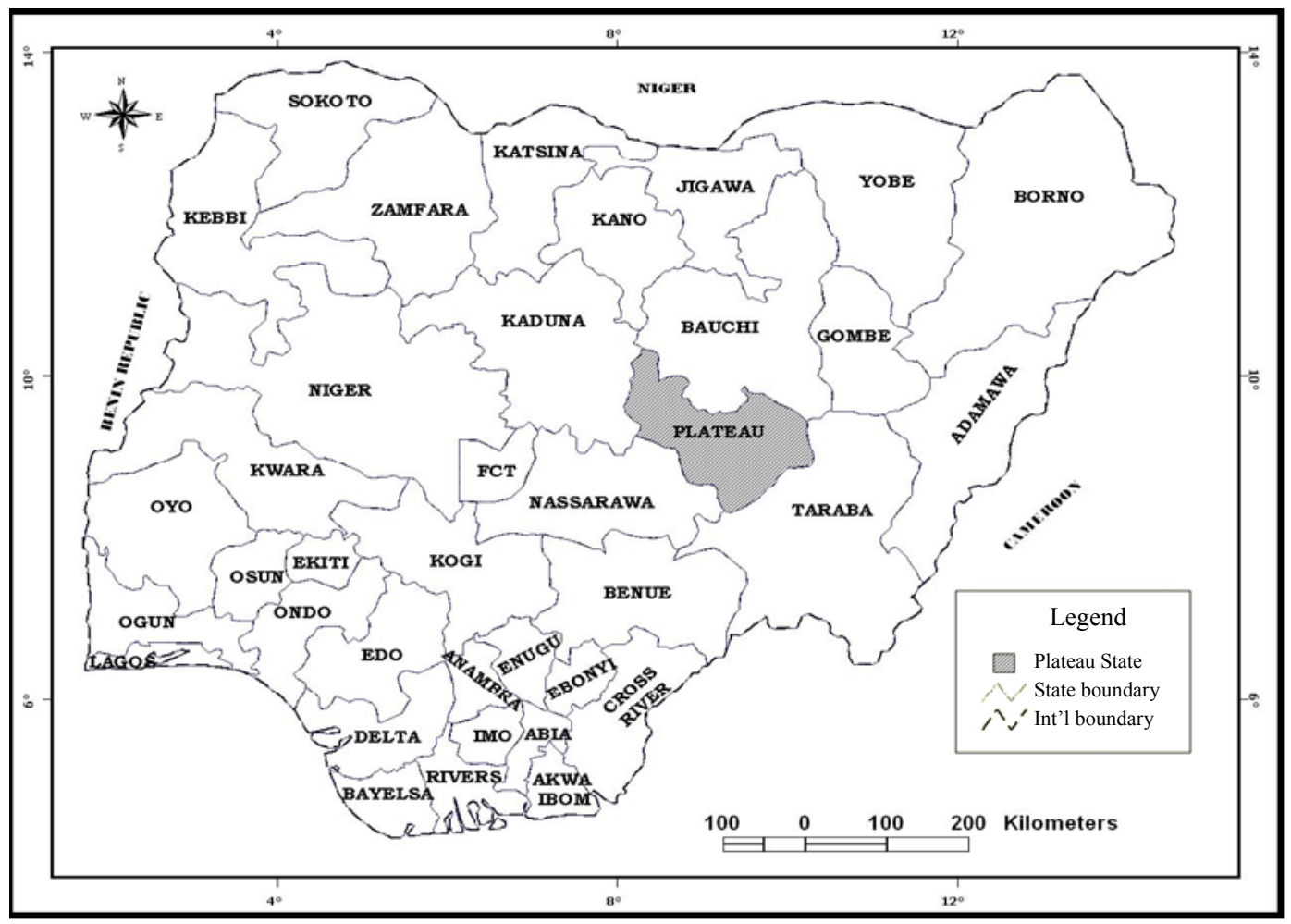

Fig. 4 Location of Plateau State.

Source: GIS Lab, University of Jos, Nigeria, 2008. 
The region has a high potential of expanding due to high level of insecurity bringing about migration from the neighbouring states. This has led to a high demand for more land for construction of houses and people resorting into the utilisation of the derelict tin-mining areas. It has a good and healthy climatic weather condition and with a low standard of living. The area is good for a large variety of vegetable and fruits cultivation throughout the year, hence the name "fruit and vegetable basket" of the nation (Nigeria).

Furthermore, it is endowed with a lot of tourism potential such as the Assop Falls, Kura Falls, Hoss Ropp Hills, the Riyom Rock, Mado Tourist Village, Rayfield Resort, Jos Wild Life Park and the Solomon Lar Amusement Park amongst others.

The processes and methods of mining have varied degrees of environmental impacts/effects on the landscape. The spoil hills that resulted from these activities by estimate occupy $325 \mathrm{~km}^{2}$ (about $41 \%$ ) of the Jos Plateau, while the area destroyed which is about $267 \mathrm{~km}^{2}$ is characterized by mining paddocks and tin tailings [23, 32, 33] in Ref. [28]. This accounts for about $30 \%$ of the land being unproductive either due to gullies with depth and width of gullies up to $12.2 \mathrm{~m}$ and $2.4 \mathrm{~m}$ respectively and to about $7,240 \mathrm{~km}$. This is manifested in the presence of the mounds and ponds that have become potential danger to human lives and affected the aesthetics of the physical environment (Figs. 5 and 6).

The tin-mining activity has affected the entire region and its effects/impacts are observed to have supported some industrial uses like food preservation, paint, plastic and pesticides (positive). It also has consequences of poisoning and affecting the soil, water, air and the environment due to the presence of heavy metals $(\mathrm{Pb}, \mathrm{As}, \mathrm{Cu}, \mathrm{Cr}$ and $\mathrm{Ni})$ and radioactive substances (X-ray, beta-ray and gamma-ray) as well as microbial contaminants which are major elements that have affected the health of the people and quality of their housing in the tin-mining region as observed in Refs. [26, 28, 34-41].



Fig. 5 Burrow pits results of pre-tin-mining activities. Source: Greater Jos Master Plan 2007.

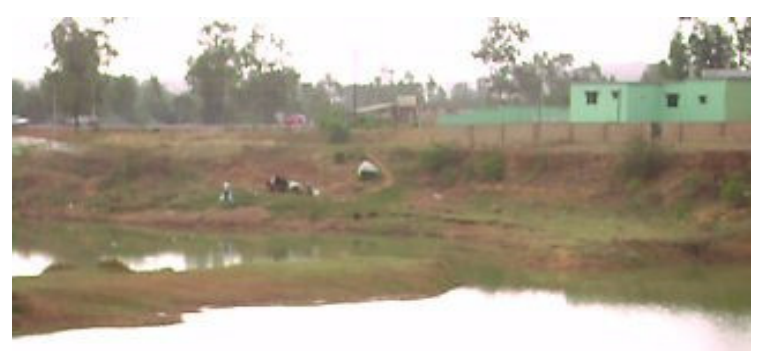

Fig. 6 Mine ponds results of pre-tin-mining activities. Source: Greater Jos Master Plan 2007.

It is against this backdrop that this paper seeks to examine the abandoned tin-mined region serving as a potential home for the people with a view to make recommendations by identifying and assessing the impact/effects of heavy metals, microbial and radioactive substances such as X-ray, beta-ray and gamma-ray on housing, water, air and soil as they affect the health of the people and by identifying and determining the level and availability of heavy metals and radioactive substances, analyzing the quantity of heavy metals and radioactive substances and compared with international required standards and finally examine the impact of the said substances on housing within the study area.

\section{Literature Review}

2.1 Heavy Metals, Radioactive Substance and Microbial Contamination in the Tin-Mining Areas

Adiuku-Brown [42] and Adiuku-Brown and Ogezi 
[43] observed that soil and tailings samples are collected from the region within which different substances are expected to be present after physical observation and survey have been carried out. The soil samples were subjected to microscopic analysis to identify the minerals in the tailings and soil samples. Substances such as uranium and thorium were identified in the tailings and soil samples obtained. Furthermore, elements of manganese, iron, cadmium, zinc and lead in the samples were also identified when further digested using $\mathrm{HNO}_{3}, \mathrm{HCL}$ and $\mathrm{HCIO}_{4}$ mixture with the soil samples and tailings. In a related study by Mohsen et al. [44], Roussel et al. [45], World Health Organization [46] and Zuhairi et al. [47] in Malaysia, other methods were used such as fusion to identify that there are reasonable quantities of the substances within the tin-mining regions.

Ayanbimpe et al. [35] considered in a related study indoor air quality and how it relates to human health. The emphasis was placed on fungi as a microbial contaminant and the health problems it poses on residents in Jos, Metropolis Nigeria. Different fungus were isolated from air in the study and varying symptoms of diseases were identified among the residents. For the purpose of this paper, radioactive substances such as X-ray, beta-ray and gamma-ray and heavy metals such as $\mathrm{Pb}, \mathrm{As}, \mathrm{Cu}, \mathrm{Cr}$ and $\mathrm{Ni}$ would be identified and its dose determined as considered by the studies used as secondary sources.

\subsection{Heavy Metals, Radioactive Substance and Microbial Contamination}

Materials analyzed were soils, water, air and tailing sample collected from various locations in the Jos metropolis, Nigeria. The samples were reported as being used for roasting and frying of groundnut, plastering and construction materials, such as for residential buildings. These samples were oven dried for soils, ground to powder and used. A weighted quantity of sample sufficient to fill a $230 \mathrm{~cm}^{3}$ cylindrical plastic cup was used for the gamma-ray counting. The samples were triply sealed and stored for a minimum of $24 \mathrm{~h}$ under a temperature of $105^{\circ} \mathrm{C}$ in an oven to dry. Other studies examining similar environmental pollution as a result of tin-mining have also employed the same method of sampling and instruments for analysis in Malaysia and Korea $[26,39,44]$. For the purpose of these paper, heavy metals such as $\mathrm{Pb}, \mathrm{As}, \mathrm{Cu}, \mathrm{Cr}$ and $\mathrm{Ni}$ would be analyzed and the dose determined as considered by the studies used as secondary sources.

This condition was checked by allowing radium to reach equilibrium. Water sample was collected from the mine ponds, well water and boreholes within the study area. The water was collected in polyethylene $250 \mathrm{~mL}$ screw cap bottles. All the vessels used for the collection of the water were sterilized. Cation analysis vessels were soaked in $2 \% \mathrm{HNO}_{3}$ (nitric acid) while for anion were soaked in 6\% HCL (hydrochloric acid) except for $\mathrm{Cl}$ analysis. Tests were made for conductivity using Esticks EC500 conductivity Jenway meter and $\mathrm{pH}$ scale and thermometer. The total hardness of water was determined using titrimetric method, while turbidity was measured using Secchi's disk [28].

For the purpose of this paper, radioactive substances such as X-ray, beta-ray and gamma-ray would be identified and dose determined as considered by the studies within the region.

2.3 Effects/Impacts of Heavy Metals, Radioactive Substances and Microbial Contamination on Housing, Water, Soil and Air

There are varying degrees of damage to the physical environment as a result of the mining activities. The impact of this activity gives rise to a plethora of substances such as heavy metals, radioactive substances and microbial contaminants. Based on the aforementioned, there are medium to long-term effects on the inhabitants within the region of activities, hence the region needs remediation to mitigate against any future effects. It is based on this insight that a careful 
consideration of the effects of the substances enumerated has become pertinent.

This section would review the effects of the heavy metals, radioactive substances and microbial substances on housing, water, soil and air as components of the environment. Proximity of ponds to residences has a multi-dimensional effect on housing because it has different facet ranging from physical, social, economic, political and cultural among others as observed by Jiriko [48].

Some of the typical environmental impacts caused by mining activities include diversion of rivers, water siltation, landscape degradation, deforestation, destruction of aquatic life habitat, and widespread pollution. Most industrial activities damage the physical environment at varying degrees. Mining industries with numerous phases of extraction processes serve as potential source of damage to the environment $[21,26,39,40,46,49,50]$.

The resultant damage through excessive mining using heavy machines and equipments has therefore become conspicuous and severe to be ignored as observed in the tin-mining areas of Malaysia, China and Jos Plateau Nigeria [39]. With the decline in the economic activity, after a rising affluence, it has left the inhabitants of the region with the mining scar characterized by mounds, ponds, tin-tailings and other hard metals which make the area vulnerable to erosion. These and many other factors have left the inhabitants without any source of livelihood. Thus, they have questioned the need for tin/cassiterite exploitation which was to bring about economic growth but has become a potential source of great pollution and a destroyer of the environment and now desiring various conservation, protection and mitigation measures to bring about a clean and healthy habitable environment $[8,21,26,46,50]$.

Tin in its natural state does not cause any harm and is not very toxic to any kind of organism in the environment, because it has both chemical and biological components. It accumulates on water and soils for many years and its concentration rises $[26,50,51]$. Ayanbimpe et al. [18] observed that when humans absorb tin bonds and other substances such as lead through food, breathing and through the skin, the intake of these substances can cause the following: eye and skin irritations, headaches, stomachaches, sickness and dizziness, severe sweating, breathlessness, urination problems and with a long-term effects such as depressions, liver damage, malfunctioning of immune systems, chromosomal damage, shortage of red blood cells, brain damage (causing anger, sleeping disorders, forgetfulness and headaches). Other symptoms such as abdominal pain, nervous disorders affecting growth and ultimately leading to kidney failure in children, especially fast growing under 5 year-old, are most at risk as observed by UNSCEAR [41], WHO [46] and Barry [52] when lead is absorbed.

Hence there is a move to strike a balance between benefitting from mineral exploration and serious damage to their environment where humans live, work and play. The effort here is geared towards achieving an environmental sustainability. According to Bruntland [2], due to the fragility of our environment, there is a need to ensure that development can meet the need of the present without compromising the ability of future generation to meet their own needs. Therefore, protecting the natural environment contains environmental impacts and reduces reliance on non-renewable resources.

Studies related to environmental impact assessment in mining sites have shown evidence of tailings transported through streams [38-40]. Mine wastes or tailings at abandoned mines left expose to air and water have produced acidic water and soils as observed by Zuhairi et al. [47]. Based on the aforementioned, tin-mining areas are not areas to be habited, but for the fact that there is pressure on land, areas that were previously abandoned, are now being habited leading to numerous problems due to pollution and contamination of soils, surface and underground water with toxic substance as observed by Ayanbimpe et al. 
[35] and Gyang and Ashano [28].

Douglas [36] had observed that there are high concentration of heavy metals, from waste and tailings, e.g., $\mathrm{Pb}, \mathrm{As}, \mathrm{Cu}, \mathrm{Cr}$ and Ni. Alshaebi et al. [34] also observed that there is mass movement resulting in large volumes of sediments of these substances to rivers (rain water dragging waste into drainage track) causing severe flooding and erosion problems in both rural and urban settlements in the region, topographic depressions compared to other locations, destruction of natural habitats, formation of wasteland (mining ponds, moulds, tailings among others), and radioactive materials which makes the region highly unhealthy for habitation [21, 28, 48, 53]. Based on this, it has become very difficult for basic infrastructure to be provided within the region. But with the pressure on land in the surrounding areas, these abandoned mine areas are now being inhabited but lack the basic infrastructure for growth and development [21, 28, 48, 53].

The source of livelihood for the inhabitants of the tin mining areas and its environs, which is land, has been made derelict. Eighty to ninety percent of the people living in these areas are peasant farmers who depend on land for their agricultural activities and as such, this has affected their socio economic life, which also serves as the bases for condition of a good quality and housing for habitation which has been depleted. Consequently, the landscape is characterized by steep sided spoils "hills", i.e., mounds of materials from excavations, multi-colored ponds or lakes, which are numbered at about $600[19,53]$.

These conditions, according to Jiriko [48], make the region unsuitable for human habitation (residential). And other land uses, which have influenced, to a large extent, the housing condition, presenting an unhealthy scenario within the region, thus Jinadu [12] described housing as the physical structure or house (temporary or permanent) which provides shelter for man plus all the auxiliary infrastructures (facilities, utilities and services) which contribute to the physical, health, mental and material wellbeing, comfort and satisfaction of individuals and their families. Consequently, the world habitat declaration about the right of humans to housing has observed that poverty has various manifestations, including lack of income, homelessness and inadequate housing, individuals and households who lack safe, secure and healthy shelter with basic infrastructure such as piped water and adequate provision for sanitation, drainage and the removal of household waters suffered from housing poverty $[4,8]$.

The extent of radioactive contamination in the mining communities has not been carefully documented by local doctors and public health specialists. Thus, multi-generational pattern of severe health effects manifest shortly after the mining activities declined, and it was possible because it affected the soil, air and water as well as the housing in the regions [18, 25, 42, 49, 53, 54].

Based on the aforementioned, the substances have profound influence on the health, efficiency, social behavior, satisfaction, productivity and general welfare of the individual and community. Thus, the importance of housing cannot be overemphasized as it relates to the provision of good health and welfare. This is not easy to the poor and low income, in spite of the numerous declarations, policies and programmes aimed at providing this basic necessity of life. The numerous national housing policies $[4,55]$ were not achieved principally due to lack of political will. The issue of housing quality has not been adequately addressed. The policies themselves are urban bias and the agencies to implement them lack institutional framework for the implementation [56].

Therefore, policy failure in Nigeria and many developing countries has created a gap in both urban and rural areas. Furthermore, most of the policies are urban bias and do not place emphasis on housing environmental quality in the rural areas. The peculiarity of the tin-mining region of Jos Plateau, Nigeria is in the fact that $80 \% \sim 90 \%$ of the settlements are located in the urban areas as a result of the sporadic 
sprawling developments which are fast engulfing the rural areas, which are basically agrarian, with peasant farmers [57].

\section{Research Methodology}

This section gives an explanation about the materials and methods used as well as the description about the study area considering the fact that the tin-mining activities have taken place leading to the exposure and availability of the radioactive substances and the heavy metals as well as microbial contaminations within the region. Samples were collected from areas around Rock Heaven, Zaria road, Jos, Kufang village off Miango road, Jos and mills extracting columbite as a main objective and from the banks of a stream in Anglo-Jos. Cassiteriate is washed directly in the stream and tailings heaped beside the stream as observed by Adiuku-Brown and Ogezi [43].

The methodology is quantitative in nature, with secondary base evidence obtained from previous works on Jos Plateau Tin-Mining Region (geological, geophysical and chemophysical field surveys).

From sheet 148 Toro north central Nigeria, it shows where samples of water and soil with tailings were taken to check for equivalent dose of the natural gamma-emitting radionuclides $\left({ }^{238} \mathrm{U},{ }^{232} \mathrm{Th}\right.$ and $\left.{ }^{40} \mathrm{~K}\right)$, as well as mineral and chemical composition. The same sample was also used to determine the hardness in water as a result of the presence of the substances in the water [28]. The instruments used include scintillator (NaI (TI)) photomultiplier to detect and take count of gamma and alpha radiation count per second, and measurements of soil natural radioactive were made using a multi-channel pulse-height analyzer (Canberra Series 10 plus) coupled to a $76 \mathrm{~mm} \times 76 \mathrm{~mm} \mathrm{Nal}$ (TI) scintillation detector [26]. While the instrument use for water is Esticks EC500 for conductivity and Jenway 3150-pH for temperature (thermometer) amongst others.

A total of 20 surface samples (soil) of natural origin were collected from a number of locations spread across the region. These were at depth levels of $0 \mathrm{~cm}$ to $6 \mathrm{~cm}$, as adopted by Ajayi [26], Macleod et al. [20] and Ibeanu et al. [37] to determine the equivalent dose in human body and in building construction materials to the natural gamma-emitting radionuclides $\left({ }^{238} \mathrm{U}\right.$, ${ }^{232} \mathrm{Th}$ and ${ }^{40} \mathrm{~K}$ ) [58]. Gross gamma and alpha radiations counts data obtained in counts per second $(\mathrm{c} / \mathrm{s})$ were converted to exposure in reagent $/ \mathrm{h}$ and these were exposure rates again converted to absorbed dose rate in $\mathrm{rad} / \mathrm{h}$ using the relation between absorbed dose rates as given by Grasty et al. [59]. A PUG-7 radiation meter combined with a T/A probe was used to measure the radiation levels in the soil samples. This generally allows for appropriate measurement depending on the strength of the radiation. Measurements of the soil's natural radioactivity were made using a multi-channel pulse-height analyzer [26]. For water, the instruments used to test different parameters were for conductivity, $\mathrm{pH}$ and temperature, the Esticks EC500 conductivity meter and Jenway 3150-pH/temperature (thermometer) meter, respectively. Total hardness was determined using titrimetric method, while turbidity was measured using Secchi's disk. Other instruments used were litmus paper for $\mathrm{pH}$ and spectrophotometer for anion analysis [28].

\section{Results and Discussions}

\subsection{Analysis: Ionizing the Radiative Substances}

The results of ionizing radiation carried out on the sample of soils from the locations in different parts of the areas with basalts on the plateau show that the gamma radiation dose rates vary from 0.03 0.058 $\mathrm{rem} / \mathrm{yr}(0.32 \sim 058 \mathrm{mSv} / \mathrm{yr})$, while dose rate due to alpha and beta radiations is from $0.16 \sim 0.32 \mathrm{rem} / \mathrm{yr}$. The total dose rate from both alpha/beta and gamma radiation from the basalts within the Jos Plateau therefore is between $0.19 \sim 0.36 \mathrm{rem} / \mathrm{yr}$. The implication of the results explains that the natural radiation levels in basalts around the Jos area are low, generally below the maximum permissible exposure for general public. This makes the basalts radiologically safe for use in 
areas such as building construction as well as domestic uses amongst others with little likelihood that safe radiation levels in such buildings will not be exceeded.

The alpha and beta gamma radiation particles when exposing are dangerous radioactive materials when taken into the body via food $[60,61]$. Hence, prior to this study, Arena [62] and Shapiro [63] had argued that ionizing radiation may cause injuries to the brain, damage of eye lens resulting in cataracts, damage to the ovaries or testes which may cause sterility and damage to the bone marrow which affects the body's ability to fight infection. The extent of radiation injury will however depend on the period of exposure, distance to source and shielding between source and target [64]. This is a corroboration with the work by Mohsen et al. [44] and Zuhairi et al. [47] in Malaysia. Other studies by Adiuku-Brown [42] and Adiuku-Brown and Ogezi [43] reveal that there is a gross significance as it relates to thorium (Th) and uranium (U) as radioactive by any given route: a decay of say, uranium-238 series, for example, consists of 14 steps, eight involving alpha decay and six involving beta decay. Radium ( $\mathrm{Ra}$ ), radon ( $\mathrm{Rn})$ and thorium (Th) are among the radionuclides emitted in the process (Table 1).

The following effects of the decay and emission of radionuclide exemplified in the use of tailings in building construction can trigger off radioactivity in building. Thus, radon is able to accumulate to hazardous levels in buildings constructed or resting on tailing. Furthermore, the use of tailings in roasting of groundnuts can lead to ingestion of radionuclide such as radon. Radon produces other products which lodge in the lungs and eventually produce lung cancer. The use of tailings in children's playground can lead to a direct ingestion of radioactive elements or their radionuclides. The general indiscriminate disposal of tailings can pose a threat to human health which is a negation of one of the 1999 national policy on environment as road fills. Tailings have no cementing material. Therefore, the radioactive elements and their radiogenic products can easily be washed into neighboring streams. Radium-226 is particularly toxic if ingested through stream waters $[65,66]$.

In addition to the radioactive elements identified in the tailings, manganese, iron, lead, cadmium and zinc were also detected during chemical analysis [43]. As a result of these findings, the following effects are possible: lead is very toxic at lower concentration $[62,65]$. Lead poisoning damages the kidney, liver, reproductive organs, central nervous system and the brain. This was observed recently in Nigeria where over 400 children were killed from lead poisoning in Zamfara state, northern Nigeria, which spread over seven villages in less than 6 months [52]. Cadmium and lead are formed from particularly stable bonds to some active sites of some proteins (enzymes) and can be associated with the protein replacing the carboxyl hydrogen, or disrupt the disulphide bridge, or replace

Table 1 Radioactive substances and radiation/ionization level in study area.

\begin{tabular}{lllll}
\hline $\begin{array}{l}\text { Hazardous } \\
\text { pollutants }\end{array}$ & Health impact & Dose rates (rem/yr) & Implication & $\begin{array}{l}\text { Substances emitted } \\
\text { (radionuclides) steps } \\
\left(x^{*}\right)\end{array}$ \\
\hline Gamma radiation & $\begin{array}{l}\text { Injury to brain, damage eye leading to cataract, } \\
\text { ovaries, testes (sterility), bone marrow and } \\
\text { inability of the body to fight infection }\end{array}$ & $0.03 \sim 0.058$ & $\begin{array}{l}\text { Low (permissible Radium (Ra) } \\
\text { exposure) }\end{array}$ & $\begin{array}{l}\text { Thorium (Th) } \\
\text { Radium (Ra) }\end{array}$ \\
\hline Alpha radiation $(\delta)$ & $\begin{array}{l}\text { Injury to brain, damage eye leading to cataract, } \\
\text { ovaries, testes (sterility), bone marrow and } \\
\text { inability of the body to fight infection }\end{array}$ & $0.16 \sim 0.32$ & $\begin{array}{l}\text { Low (permissible (-226 series) } \\
\text { exposure) }\end{array}$ & $\begin{array}{l}\text { Thorium (Th) } \\
\text { Uranium (U) } x 8\end{array}$ \\
\hline & $\begin{array}{l}\text { Injury to brain, damage eye leading to cataract, } \\
\text { ovaries, testes (sterility), bone marrow and } \\
\text { inability of the body to fight infection }\end{array}$ & $0.16 \sim 0.32$ & $\begin{array}{l}\text { Low (permissible Thorium (Th) } \\
\text { exposure) }\end{array}$ & $\begin{array}{l}\text { Uranium (U) } x 6 \\
(-238 \text { series) }\end{array}$ \\
\hline
\end{tabular}

$*_{x}$ means number of times a particle is available.

Source: adopted from Adiuku-Brown and Ogezi [43]. 
Table 2 Health impact of hazardous pollutants (heavy metals and radioactive substances).

\begin{tabular}{|c|c|c|c|}
\hline $\begin{array}{l}\begin{array}{l}\text { Hazardous pollutants } \\
\text { (heavy metals) }\end{array} \\
\end{array}$ & Health impact & $\begin{array}{l}\text { Dose rates (ppm) and } \\
\text { implication }\end{array}$ & Constituent elements \\
\hline Monozite & - & - & Ce, La,Sn, Th, U in traces \\
\hline Zircon & - & - & Zr, Y,Sn, Fe, U \\
\hline Zinc & Toxic in high concentration & 430 & $\mathrm{Zn}$ \\
\hline Lead & $\begin{array}{l}\text { Damages kidney, liver, reproductive } \\
\text { organs, central nervous system and } \\
\text { brain }\end{array}$ & $\begin{array}{l}413 \text {; disrupt disulphide bridge, denature } \\
\text { protein and impaired normal metabolic } \\
\text { activities in the body }\end{array}$ & $\mathrm{Pb}$ \\
\hline Manganese & Toxic in high concentration & 800 & $\mathrm{Mn}$ \\
\hline Cadmium & $\begin{array}{l}\text { Form a stable bond to protein } \\
\text { enzymes and denaturing it }\end{array}$ & $\begin{array}{l}\text { 2.0; disrupt disulphide bridge, denature } \\
\text { protein and impaired normal metabolic } \\
\text { activities in the body }\end{array}$ & $\mathrm{Cd}$ \\
\hline Columbite & $\begin{array}{l}\text { Eye, brain, skin and blood related } \\
\text { diseases }\end{array}$ & Damage of cells of organs listed & $\mathrm{Nb}, \mathrm{Fe}, \mathrm{Mn}, \mathrm{Ta}, \mathrm{Sn}$ \\
\hline Cassiterite & $\begin{array}{l}\text { Eye, brain, skin and blood related } \\
\text { diseases }\end{array}$ & Damage of cells of organs listed & $\mathrm{Sn}, \mathrm{Nb}$ \\
\hline $\mathrm{Fe}_{2} \mathrm{O}_{3}(\%)$ & Toxic in high concentration & 16.14 & \\
\hline $\mathrm{SnO}_{2}(\%)$ & & 0.32 & \\
\hline
\end{tabular}

Source: adopted from Adiuku-Brown and Ogezi [43].

Table 3 Minerals and mean concentration of constituent elements.

\begin{tabular}{llll}
\hline Minerals & Constituent elements & Analysis & Mean concentration by heavy metals \\
\hline Columbite & $\mathrm{Nb}, \mathrm{Fe}, \mathrm{Mn}, \mathrm{Ta}, \mathrm{Sn}$ & $\mathrm{Cd}(\mathrm{ppm})$ & 2.0 \\
Cassiterite & $\mathrm{Sn}, \mathrm{Nb}$ & $\mathrm{Mn}(\mathrm{ppm})$ & 800 \\
Zircon & $\mathrm{Zr}, \mathrm{Y}, \mathrm{Sn}, \mathrm{Fe}, \mathrm{U}$ & $\mathrm{Zn}(\mathrm{ppm}), \mathrm{Pb}(\mathrm{ppm})$ & 430,413 \\
Monozite & $\mathrm{Ce}, \mathrm{La}, \mathrm{Sn}, \mathrm{Th}, \mathrm{U}$ in traces & $\mathrm{Fe}_{2} \mathrm{O}_{3}(\%), \mathrm{SnO}_{2}(\%)$ & $16.14,0.32$ \\
\hline
\end{tabular}

Source: adopted from Adiuku-Brown and Ogezi [43].

the hydrogen of the sulphydryl group, denaturing the protein and impairing its normal metabolic activities [67]. Some heavy metals (zinc, iron and manganese) which, in normal concentrations, are essential components of biochemical systems are toxic when present in the body in higher concentrations (Table 2) $[68,69]$.

The conclusion drawn by Adiuku-Brown and Ogezi [43] was that it is unsafe to use the mill tailings scattered in major locations in residential areas and streams channel to build houses or roast groundnut as they contain radioactive materials and toxic elements. Tailings should be properly disposed of in a carefully sited location earmarked strictly for the purpose. There is the need to carry out extensive public enlightenment on the possible hazards that can accompany the indiscriminate disposal and utilization of tailings, and monitor compliance.

\subsection{Analysis: Microscopic, X-Ray Fluorescence and Chemical}

The microscopic analysis was to identify the minerals in tailings: the crystal of zircon (uranium incorporated due to similarity in size and charge) and thorium in monazite as well as uranium. The X-ray fluorescence was essential for the identification of the presence of uranium and thorium in the tailings obtained. The elements are manganese, iron, cadmium, zinc and lead and the samples were digested using $\mathrm{HNO}_{3}, \mathrm{HCL}$ and $\mathrm{HCIO}_{4}$ mixture. Fusion with $\mathrm{Na}_{2} \mathrm{CO}_{3}$ and $\mathrm{Na}_{2} \mathrm{O}_{2}$ was used in the digestion of samples for $\mathrm{SnO}_{2}$ determinations. Reagents blanks were also prepared and standards were digested and analyzed along with samples to apply some correction factors. UNICAM (brand name for the instrument) atomic absorption spectrophotometer was used for the analysis (Table 3) [43]. 


\subsection{Water Analysis}

Results for water analysis show that the tin-mining activities carried out on the project did not affect the quality of the water, though there are traces of manganese, iron, and chromium observed in some samples which cannot be said to be significant enough to warrant panic, except for fear of bioaccumulation [28, 42, 43].

In a related study by Ayanbimpe et al. [49], it was observed that water obtained from about 150 sources within the study area (residential area) was that fungi has affected the water sources and that it is significant. The different sources of water are visited by a large number of people for activities ranging from bathing and washing as well as irrigation which are eventually transferred to vegetables. The implication of this is the prevalence of fungal infections.

\subsection{Housing Analysis}

For the purpose of analysis on housing conditions, five level scales were used to determine the level of quality. Depending on the conditions of the various parts of the building viz: very good, good, fair, poor or derelict, using variables that determine the functionality and satisfaction of the housing facilities, such basic amenities, materials use for the construction of the buildings all contribute to the conditions and quality (Table 4) [6, 8, 13, 60].
From other research conducted, houses/structures were built on polluted lands and soils with contaminants were used as building materials while water containing such contaminants is used for construction, domestic purpose and sanitation. The air in most of the houses has dust that contains these contaminants (indoor air fungi). More than $75 \%$ of respondents had complaints of respiratory systems, frequent headache, eye irritation and skin rash. Sixty-one percent of the homes showed dampness of the indoor environment, with more than $50 \%$ of the settlements not within the planned areas. Sixty percent of the houses lack proper drainages, toilets and waste disposal facilities and $43 \%$ of the houses were old and some dilapidated (Table 5).

The above analysis has shown the extent of environmental pollution and its impact on the health of local residence. It is important to assert that half of the households surveyed fall outside what is termed as planned area. This has further implication as it demonstrates the ineffectiveness of the planning system and lack of environmental protection. The Jos metropolis and local government authorities seem unable to do anything about this environmental hazard. This could be attributed to lack of resources including finance, legislative and institutional capacity in terms of planning and control. In the area of planning, the local governments in the metropolis should have urban and regional planning departments, create and monitor

Table 4 Conditions and characteristics of buildings in the study area.

\begin{tabular}{lll}
\hline $\begin{array}{l}\text { Condition of } \\
\text { buildings }\end{array}$ & Characteristics & Implication \\
\hline Very good & $\begin{array}{l}\text { No need for repairs, have the needed basic amenities such as water, electricity, } \\
\text { kitchen, toilets, good refuse/sewage disposal and in a good environmental } \\
\text { quality }\end{array}$ & $\begin{array}{l}\text { The building is physically and } \\
\text { structurally sound }\end{array}$ \\
\hline Good & $\begin{array}{l}\text { Requires minimum level of repairs. It must have sound foundation and walls, } \\
\text { with little or no cracks or leakages on the roof, with the needed basic amenities is structurally sound }\end{array}$ \\
\hline Fair & $\begin{array}{l}\text { Have cracks on the walls, leaking roofs, and broken windows to enhance its } \\
\text { physical condition and bring it back to its original state. It may be lacking in } \\
\text { some basic amenities }\end{array}$ & $\begin{array}{l}\text { The buildings structurally require some } \\
\text { level of repairs }\end{array}$ \\
\hline Poor & $\begin{array}{l}\text { Devoid of basic amenities, and when available are not adequate. Some parts } \\
\text { of the buildings have collapsed and are not habitable. Such houses require } \\
\text { immediate reconstruction and they may not have possess any facilities at all }\end{array}$ & $\begin{array}{l}\text { The physical structure of the building } \\
\text { requires major/minor repairs or } \\
\text { renovation and may require urgent } \\
\text { attention in order to upgrade the building } \\
\text { and make it habitable (derelict state) }\end{array}$ \\
\hline
\end{tabular}

Source: Wapwera [16], Wapwera et al. [57] and Ayanbimpe et al. [35]. 
Table 5 Occurrence of fungal contamination of indoor air within the JPTMR (Jos Plateau Tin-Mining Region).

\begin{tabular}{lcl}
\hline Features of questionnaire & Number of positive responses & Number of fungal isolates (\%) \\
\hline Unplanned settlement & 72 & $55(14.7)$ \\
Age of building (old) & 61 & $43(11.3)$ \\
Lack of toilet/drainage facility & 87 & $24(6.3)$ \\
Lack of waste disposal facility & 87 & $45(11.8)$ \\
Dampness of building & 87 & $87(22.9)$ \\
Mold growth in the home & 17 & $42(11.1)$ \\
Symptoms (respiratory, eye) & 106 & $24(6.3)$ \\
Arthropod infestation & 126 & $60(15.8)$ \\
\hline
\end{tabular}

Source: Ayanbimpe et al. [35].

Table 6 Chronology of development of mines resort.

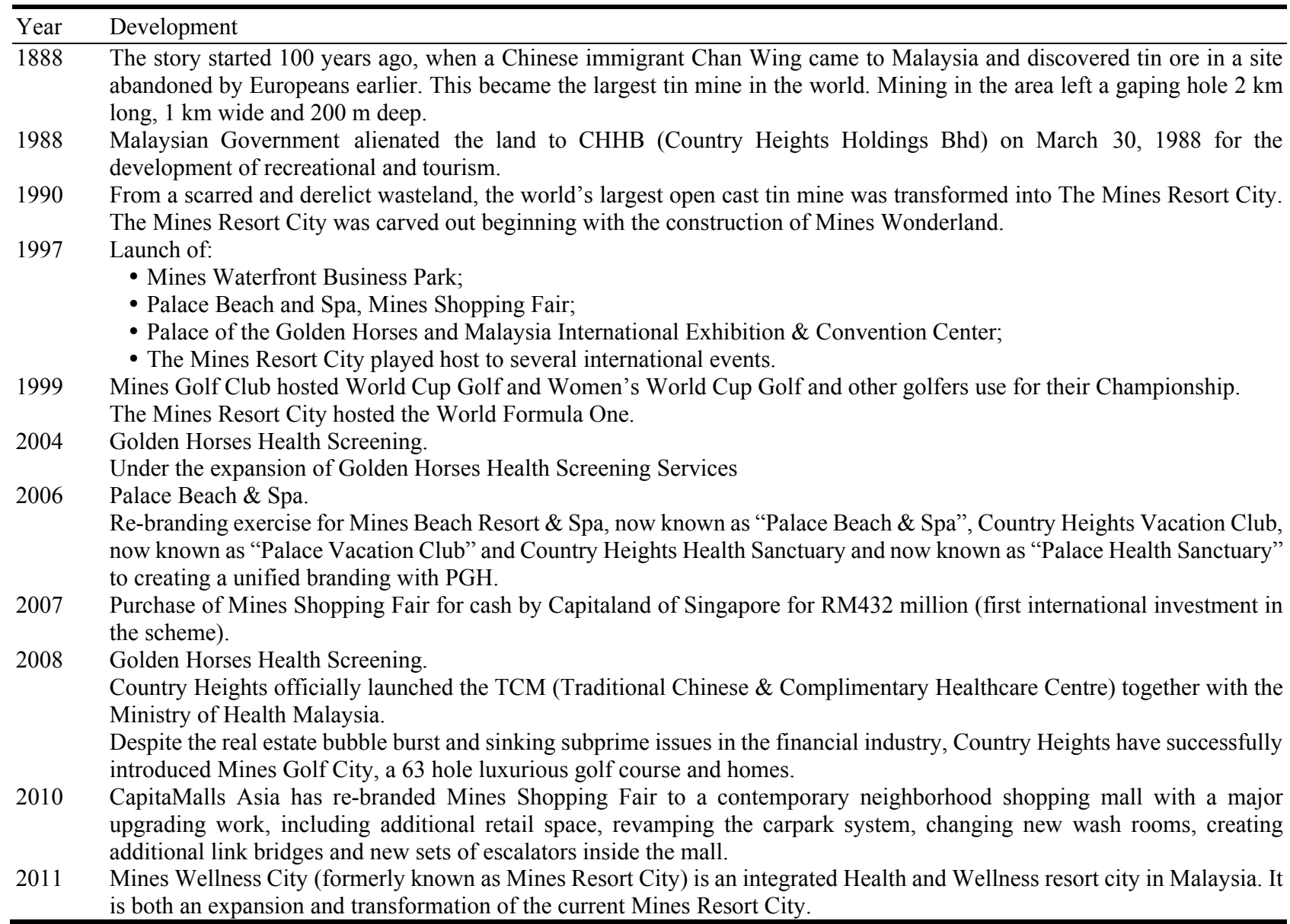

Source: http://www.countryheights.com.my/mrc.php and http://en.wikipedia.org/wiki/Mines_Wellness_City.

developments, as well as make funds available for development control at that level as observed in the 1992 URP (Urban and Regional Planning) Law.

This next section examines alternative solution to development of contaminated land. This is achieved through examination of the case study mines in Malaysia where private developer has transformed former tin-mining area into a thriving, safe and quality area.

\subsection{Alternative Solution to Development of Contaminated Land}

Drawing from international experience, a case study of how a former tin-mining area has been used to 
develop mixed use housing, business and recreation centre through careful remediation of the engagement of public and private partnership is presented. A typical example is the Bukit Buruntung, Kuala Lumpur Malaysia called the "Mine City" [67, 70].

Mine city (formerly known as Mines Resort City) is an area located $40 \mathrm{~km}$ north of Kuala Lumpur, Malaysia, that has experienced tin-mining activities some years back. This area is about 840 ha of land with all the features of a derelict environment, just as the Jos Plateau Tin-Mining Region. A private developer Mines Excellence Golf Resort Bhd built three five-star hotels within its RM3 billion, another developer Mines Golf City development in Bukit Beruntung, Selangor also developed on that same piece land. They developed and set up a boutique hotel, a wellness hotel with golden standards and a hotel for golfers for more than RM300 million [67].
The developer intends to establish a university designed for golfers and a health clinic and spa. And to turn Mines City into a world-class destination for golfing and for health tourism, the developer sets up a few golf and wellness hotels in Malaysia and it would be ideal to have two in Mines City, involving other boutique hotel and spa operators to be involved to set up shops at the golf resort. The 840 ha Mines City is being developed by MGC (Mines Golf City) Sdn Bhd. There are 70:30 joint ventures (partnership) between Mines Excellence and Country Heights Holdings Bhd. MGC is launching the development of a 63-hole golf course on 320 ha, which would be Malaysia's largest. The development includes townhouses, 500 bungalow lots, an equestrian and driving academy, schools, sports facilities, food outlets and parks on the remaining land [67]. Table 6 outlines the history of Mines City from its inception.

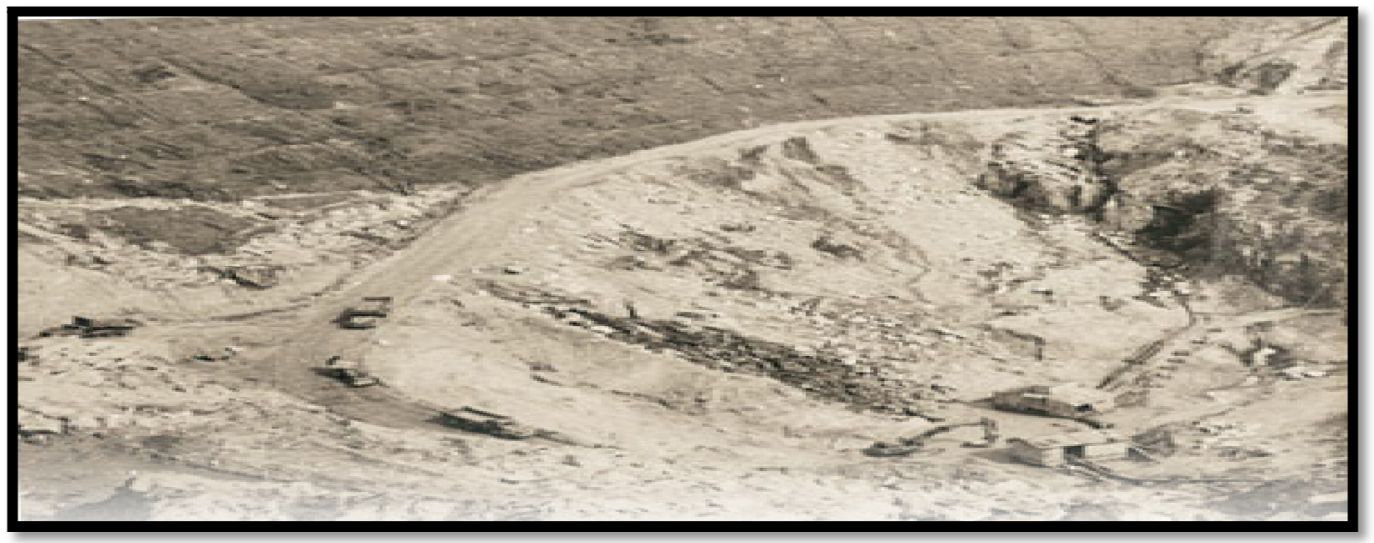

(a)

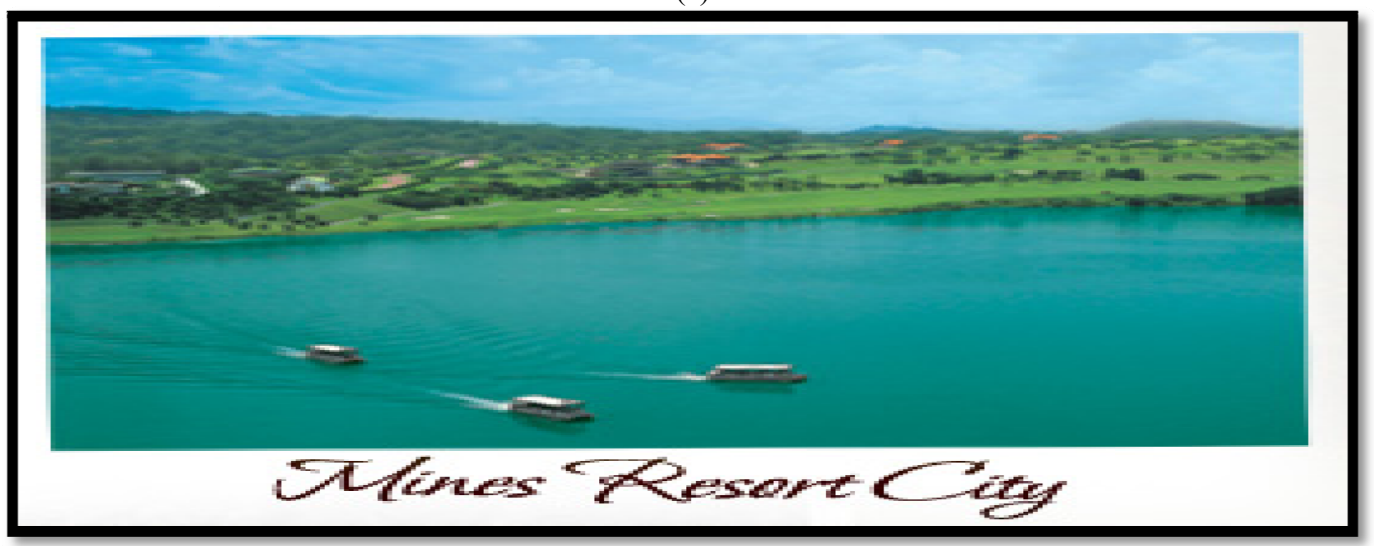

(b)

Fig. 7 The development of the derelict area into a tourist haven, before and after: (a) comparison between derelict tin mine and Mine Resort in Malaysia; (b) Mines Resort City in Malaysia (Kuala Lumpur). 
The expansion of the city is part of the Malaysian Government's ETP (Economic Transformation Plan) which is spearheaded by PEMANDU (Performance Management and Delivery Unit), under the Prime Minister's Department. The development of Mines Wellness City will lead and contribute to increased economic activity, job opportunities and GNI (gross national income). By the year 2020, the city is envisioned to be a RM5.5 billion development, playing a central role in tourism and becoming the foremost wellness destination in the country and in the south east of Asia.

Mines Wellness City showcases the company's legendary transformation of a derelict tin mine, devoid of economic and social value, to an internationally-acclaimed venue that showcases superior wellness facilities and practices (Fig. 7).

\section{Conclusions}

This paper seeks to examine the abandoned tin-mined region serving as a potential home for the people with a view to make recommendations by identifying and assessing the impact/effects of heavy metals, microbial and radioactive substances such as $\mathrm{X}$-ray, beta-ray and gamma-ray on housing, water, air and soil. It is evident that the area has been rendered derelict and identified the presence of radioactive substances such as alpha/beta and gamma radiation with a total dose rate between $0.19 \sim 0.36 \mathrm{rem} / \mathrm{yr}$ with uranium and thorium in the tailings obtained and heavy metals such as elements of manganese, iron, cadmium, zinc and lead in the samples.

Furthermore, it has left a legacy of hazardous impact on the inhabitants of the area taking away their fortunes (socio economic potential) which determine, to a large extent, their provision of basic infrastructure such as housing in a decent environment. The determination of the level of these substances shows that the environment is not habitable, but it is possible, lessons drawn from international experience such as Malaysia have proven beyond doubt that such environments could be transformed into a habitable area. The devastation from the mining activity has affected the physical landscape of the area, making it difficult for the provision of urban facilities, utilities and services. Other impacts are felt on the soils, water and air which have culminated into different life experience for the inhabitants. The Jos Plateau Tin-Mining Region examined is contaminated by heavy metals and radioactive and microbial substances and hence not completely safe for habitation. The impacts/effects are evident, as it affects water, soil, air and housing but it can be ameliorated by making policies that would make room for reclamation and good strategies put in place to prevent further occurrences. Based on these, the following recommendations are made:

- Adopting environmentally friendly techniques that would minimize the impact of tin-mining exploitation and exploration on the environmental mining mounds, ponds and heavy metals and radioactive substances and microbial on that affect, the housing, air, water and soil have rendered the area derelict;

- Measures should be put in place by all stakeholders NGOs (non-government organization), CBOs (community based organization), governments, both private and public developers to mitigate the effects and impacts of the presence of the substances within and outside the region;

- Environmental reclamations should be enforced by government and the exploration and exploiting companies;

- Measures should be put in place to checked and regulated building activities by the inhabitants in the absence of planning authority in the study area;

- Research institutions should be established to research into the development and environmental management of the derelict areas;

- Public education and awareness campaign should be continuous and consistent to create awareness about dangers of contamination as a result of hazardous substances that have effect on human health and 
well-being;

- The areas should be constituted within the jurisdiction of the planning authorities both in the state and local government level to regulate artisanal mining activities to prevent similar occurrence in other areas and should be put in place.

\section{References}

[1] Agbola, T., and Kassim, F. 2007. "Conceptual and Theoritical Issues in Housing." In Housing Development and Management: A Book of Readings, edited by Agbola, T., Egunjobi, L., and Olatubara, C. Ibadan: Department of Urban and Regional Planning, Faculty of the Social Sciences, University of Ibadan.

[2] Bruntland, G. 1987. Our Common Future: The World Commission on Environment and Development. Oxford: Oxford University Press.

[3] IPCC (International Programme on Climate Change). 2007. Climate Change. Working Group II: Impacts, Adaptations and Mitigation of Climate Change. Fourth assessment report.

[4] NHP (National Housing Policy). 2006. Policy Document of the Federal Republic of Nigeria. Nigeria: NHP.

[5] Obateru, R. I. 2004. Land Subdivision Basics. Nigeria: Penthouse Publications.

[6] Onibokun, P. 1990. Urban Housing in Nigeria. Ibadan: NISER (National Institute Social and Environmental Research) Limited.

[7] Rydin, Y. 2011. The Purpose of Planning Creating Sustainable Towns and Cities. UK: The Policy Press.

[8] Wapwera, S. 2008. "Housing Conditions in Selected Tin Mining Regions of Jos Plateau." Unpublished M.Sc. thesis, University of Jos.

[9] Ajaegbu, H. I. 1986. "Mining and Land Degradation on the Jos Plateau." Presented at the 24th Annual Conference of Nigeria Geographical Association, Kano.

[10] Dorman, M. J. 1978. "Problems of Soil Erosion on the Jos Plateau in Ajaegbu and Planning in Nigeria." In Proceedings of the 21st Annual General Conference of Nigerian Geographers Association, 20-32.

[11] Mabogunje, A. L. 1978. "Environmental Challenges of Sub-Saharan Africa Centre for Advanced Social Sciences." Monograph, Centre for Advanced Social Sciences.

[12] Jinadu, A. M. 2004. Understanding the Basic of Housing. Kaduna State: King James Publishers.

[13] Anderson, L. 2000. Planning the Built Environment. Chicago: Planners Press, American Planning Association.

[14] Ibeanu, I. G. E. 1999. "Assessment of Radiological Impacts of Tin Mining Activities in Jos and Its Environs." Unpublished Ph.D. thesis, Ahmadu Bello University Zaria
Nigeria.

[15] Ike, E. 2010. Ionizing Radiation, Man and the Environment. Inaugural lecture.

[16] Wapwera, S. 2010. "Impact of Tin Mining Activities on Housing System in the Tin Mining Regions of Jos Plateau." Unpublished thesis, Nigeria Institute Town Planner.

[17] Agbola, T., Egunjobi, L., and Olatubara, C. O. 2007. Housing Development and Management: Ibadan. Ibadan: Malijoesoftprint.

[18] Ayanbimpe, G., Wapwera, S., and Kuchin, D. 2010. "Indoor Air Mycoflora of Residential Dwellings in Jos Metropolis." Journal of African Health Sciences 10 (2): 172-6.

[19] Eziashi, A. C. 2000. "Harnessing the Mine Ponds of Plateau for Rural Development." Journal of Environmental Sciences 8 (1): 12-22.

[20] Macleod, W. N., Turner, D. C., and Wright, E. P. 1971. "The Geology of Jos Plateau." Bulletin Geological Survey of Nigeria 32 (1): 12-47.

[21] Benevento, M., Mascaro, I., Corsini, F., Lattanzi, P., Parrini, P., and Tanelli, G. 1997. "Mine Waste Dumps and Heavy Metal Pollution in Abandoned Mining District of Boccheggiano South Tuscary, Italy." Environmental Geology 30: 238-43.

[22] RICS (Royal Institute of Chartered Surveyors). 2006. Education Trust Annual Review of the RICS Education Trust. RICS report. Accessed July 20, 2011. http://www.rics.org.

[23] Howard, W. J. 1975. Central Nigeria Project: Rehabilitation of Tin Mining Land on the Jos Plateau. L.R.D (land reclamation and development) report.

[24] Mendie, A. 2009. "Nature \& Extent of the Dynamics Which the Tin Mining Industry Has Brought to Jos Plateau Tin Mining Region." Unpublished Ph.D. thesis, University of Jos.

[25] Mohsen, N., Ismail, B., and Pauzi, A. 2005. “Assessment of Natural Radioactivity in Water and Sediment from among (Tin Tailing) Process Pounds." In Proceeding of the 18th Malaysian Analytical Chemistry Symposium SKAM-18, 293-304.

[26] Ajayi, I. R. 2008. “An Evaluation of the Equivalent Dose Due to Natural Radioactivity in the Soil Round the Consolidated Tin Mine in Baukuru-Jos, Plateau State of Nigeria." Iranian Journal of Radiation Research 5 (4): 203-6.

[27] Turner, D. C. 1976. "Structure and Petrology of the Younger Granite Ring Complexes of Nigeria.” In Geology of Nigeria, edited by Kogbe, C. A. Lagos Nigeria: Elizabethan Publ. Co..

[28] Gyang, J. D., and Ashano, E. C. 2010. "Effects of Mining on Water Quality and the Environment: A Case Study of Parts of the Jos Plateau, North Central Nigeria." Pacific 
Journal of Science and Technology 11 (1): 631-9.

[29] Bingel, A. M. 1978. Jos: Origin and Growth of the Town (1900-1972). Nigeria Jos Plateau State: University of Jos.

[30] NPC (National Population Commission). 2009. A Report of the 2006 National Population Census and Housing Survey in Nigeria. NPC.

[31] Jos Metropolitan Development Board. 2008. Greater Jos Master Plan 2008-2025. Proposed urban master plan prepared for the Jos urban metropolis.

[32] Aguigwo, E. N. 1997. "The Characteristics and Viability of Informal Mining on the Jos Plateau." Ph.D. thesis, University of Jos.

[33] UNCEAR (United Nations Scientific Committee on Effects of Atomic Radiation). 1988. Exposure from Natural Sources of Radiation. UNCEAR report.

[34] Alshaebi, F. Y., Yaacob, W. Z. W., Samsudin, A. R., and Alsabahi, E. 2009. "Risk Assessment at Abandoned Tin Mine in Sungai Lambing, Pahang, Malaysia." Electronic Journal of Geotechnical Engineering 14 (Bundle D): 1-9.

[35] Ayanbimpe, G. M., Wapwera, S. D., and Okolo, M. O. 2011. "Relationship between Fungal Contamination of Indoor Air and Health Problems of Some Residential Dwellings in Jos Metropolis." Journal of African Health 10 (2): $172-6$.

[36] Douglas, I. 1996. "The Impact of Land-Use Changes, Especially Logging, Shifting Cultivation, Mining and Urbanization on Sediment Yields in Humid Tropical Southeast Asia: A Review with Special Reference to Borneo." In Global Regional Perspectives Proceedings of the Exeter Symposium, 464-71.

[37] Ibeanu, I. G. E., Akpa, T. C., and Mallam, S. P. 2004. "Radiological Assessment of Some Nigerian Soils and Tin Tailings for Building Construction Materials." Zuma Journal of Pure and Applied Sciences 6 (2): 34-48.

[38] Leblanc, M., Morales, J. A., Borrego, J., and Elbaz, P. 2000. "4500 Year-Old Mining Pollution in South Western Spain: Long Term Implication for Modern Mining Pollution." Economic Geology 95: 655-62.

[39] Lee, C., Chon, H., and Jung, M. 2001. "Heavy Metals Contamination in the Vicinity of the Daduk, Au-Ag-Pb-Zn Mine in Korea." Apply Geochem 6: 1377-86.

[40] Marques, M. J., Martinez-Conde, E., Rovira, J. V., and Ordonez, S. 2001. "Heavy Metals Pollution of Aquatic Ecosystems in the Vicinity of a Recently Closed Underground Lead-Zinc Mine Basque Country, Spain.” Environment Geology 40: 1125-37.

[41] UNSCEAR. 1998. Sources, Effects and Risks of Ionizing Radiation. New York: United Nations Sales Publication.

[42] Adiuku-Brown, M. E. 2004. "Effects of Cassiterite Mining and Associated By-products on the Environment: A Study of Some Trace Elements in Jos Plateau and Zurak Mining Districts, North Central Nigeria." Ph.D. thesis,
University of Jos.

[43] Adiuku-Brown, M. E., and Ogezi, A. E. 2004. "The Utilization of Mill Tailings on Jos Plateau: A Need to Exercise Some Restraint." African Journal of Natural Science 7: 1-8.

[44] Mohsen, N., Ismail, B., and Pauzi, A. 2007. "Gamma Hazards and Risk Associated with Norm in Sediment Amang Processing Recycling Ponds." The Malaysian Journal of Analytical Sciences 11 (1): 314-23.

[45] Roussel, C., Neel, C., and Bril, H. 2000. "Minerals Controlling Arsenic and Lead Solubility in an Abandoned Gold Mine Tailings." The Science of the Total Environment 263: 209-19.

[46] WHO (World Health Organization). 1993. WHO Document ICP/CEH 109 (S). 21. Working group committee report.

[47] Zuhairi, W., Syuhadah, N., and Abdil-Mutalib, H. 2008. "Acid Mine Drainage and Heavy Metals Contamination at Abandoned and Active Mine Sites in Pahang. Geoconservation, Geotourism and Geohazard." Presented at National Geosciences Conference, Ipoh, Malaysia.

[48] Jiriko, K. G. 2001. Aspects and Tropical Issues in Urban And Regional Planning Practices. Vol. 1. Kaduna State Nigeria: Mba Print and Graphic.

[49] Ayanbimpe, G. M., Abbah, V. E., and Ior, C. A. 2012. "Yeasts and Yeast-Like Fungal Contaminants of Water Used for Domestic Purposes in Jos, Nigeria." Microbiology Research 3 (24): 99-102.

[50] Butt, N. 2010. "Environment, Mining and the Lesser Developed Countries." Spinger-Journal Article 3: 93-101.

[51] Alshachi, Y. 2009. "Risk Assessment at Abandoned Tin Mine in Sungai Lambing, Pahang, Malaysia. Analysis of Informal Settlement Upgrading and Critique of Existing Methodological Approaches." Habitat International 26: 303-15.

[52] Barry, M. 2010. "Lead Poisoning Kills Hundreds of Children.” Nigeria Vanguard Newspaper, October 19.

[53] Ibeanu, I. G. E. 2003. "Tin Mining and Processing in Nigeria: Cause for Concern." Journal of Environmental Radioactivity 64 (1): 59-66.

[54] Agbola, T., Nwokoro, I., and Kassim, F. 2007. "Housing and Health." In Housing Development and Management: A Book of Readings, edited by Agbola, T., Egunjobi, L., and Olatubara, C. Ibadan: Department of Urban and Regional Planning, Faculty of the Social Sciences, University of Ibadan.

[55] NHP. 1991. National Housing Policy Nigeria. Nigeria: NHP.

[56] Dung-Gwom, J. Y., Hirse, S. O., and Pwat, S. P. 2008. Four-Year Strategic Plan for Urban Development and Housing in Plateau State (2008-2011). Nigeria: The Plateau State Strategic Plan Committee. 
[57] Wapwera, S. D., Parsa, A. G., and Egbu, C. O. 2011. "Financing Low Income Housing in Nigeria." Journal of Financial Management of Property and Construction 16 (3): 283-301.

[58] Beretka, J., and Mathew, P. J. 1985. "Natural Radioactivity of Australian Building Materials, Waste and Byproducts." Health Physics 48: 87-95.

[59] Grasty, R. L., Carson, J. M., Charbonneau, B. W., and Holman, P. B. 1984. "Natural Background Radiation in Canada." Geological Survey of Canada Bulletin 360: 39.

[60] UNSCEAR. 1993. Sources, Effects and Risks of Ionizing Radiation. New York: United Nations Sales Publications.

[61] WHO. 1993. Guidelines for Drinking Water Quality. 2nd ed.. Vol. 1. Geneva: WHO.

[62] Arena, V. 1971. Radiation Dose and Radiation Exposure of the Human Population. In Ionization Radiation and Life. St Louis: The C.V. Mosby.

[63] Shapiro, J. 1972. Radiation Protection. Cambridge: Harvard University Press.

[64] Solomon, A. O., Ike, E. E., Ashano, E. C., and Jwanbot, D. N. 2002. "Natural Background Radiation Characteristics of Basalts on the Jos Plateau and the Radiological Implication of the Use of the Rock for House
Construction." African Journal of Natural Sciences 5: 23-9.

[65] Sawyer, C. N., and McCarthy, P. I. 1967. Chemistry for Sanitary Engineers. 2nd ed.. New York: McGraw Hill.

[66] US EPA (Environmental Protection Agency). 2005. "Radium 226, 228 (Last Updated 10/15/1993) Integrated Risk Information System.” US Environmental Protection Agency. Accessed July 3, 2011. http://www/subst/0295.html.

[67] Kaur, S. 2009. "Mines Excellence Plans 5-Star Hotels in Bukit Beruntung." Accessed July 13, 2011. http://www.btimes.com.my/Current_News/BTIMES/artic les/lee1a/Article/\#ixzz2s7JuWBVV.

[68] Forstner, U., and Wittmann, G. T. W. 1983. Metal Pollution in the Aquatic Environment. 2nd ed.. Berlin: Springer.

[69] Schwab, P., Zhu, D., and Banks, M. K. 2007. "Heavy Metal Leaching from Mine Tailing as Affected by Organic Amendments." Bio Resource Technology 98: 2935-41.

[70] Sharman, H. D., and Reddy, K. R. 2004. Geo-environmental Engineering: Site Remediation, Waste Containment and Emerging Waste Management Technology. New Jersey: John Wily \& Sons, Inc. 